\title{
Teacher and Student Perceptions of Earth Science and Its Educational Value in Secondary Schools
}

\author{
Jason P. Betzner1, Edmund A. Marek ${ }^{2}$ \\ ${ }^{1}$ Earth Science Teacher at Hampton City Schools, Hampton, USA \\ 'John W. Renner Science Education Center, Jeannine Rainbolt College of Education, University of Oklahoma, \\ Norman, USA \\ Email: jbetzner@vt.edu, eamarek@ou.edu
}

Received 11 February 2014; revised 5 March 2014; accepted 26 March 2014

Copyright (C) 2014 by authors and Scientific Research Publishing Inc.

This work is licensed under the Creative Commons Attribution International License (CC BY).

http://creativecommons.org/licenses/by/4.0/

c. (i) Open Access

\begin{abstract}
Earth science educators struggle to gain an equal footing in the K-12 curriculum with the life and physical sciences. The low number of students taking Earth sciences courses is at odds with the National Science and Education Standards (National Research Council, 1996, 2012) that gives equal emphasis to Earth and space science (ESS). The purpose of this investigation was to analyze students' and teachers' perceptions of Earth science and its perceived educational values in secondary schools. The sample for this study consisted of 39 science teachers in public secondary schools, and 46 students taking science in those schools. The instruments for the study included a 14-item Earth Science Teacher Survey (ESTS) and a 14-item Earth Science Student Survey (ESSS) (surveys modified from King, 2001). The results of this study showed that teachers do not think that ESS is as important to the secondary school curriculum as physics, chemistry, and biology. Not unexpectedly, Earth science teachers had more positive perceptions of Earth science and its educational value than non-Earth science teachers. Students in this study had more positive perceptions of Earth science and its educational value than teachers. These students also reported a high level of enjoyment learning about Earth science and a high interest in learning about ESS topics.
\end{abstract}

\section{Keywords}

Earth Science, Educational Value, Perceptions, Secondary Schools

\section{Introduction}

A lack of qualified teachers and low enrollment in the geosciences exists at the secondary school level in the 
United States (Lewis \& Baker, 2010). Earth and space science (ESS) is defined as any subject that involves concepts of geology, oceanography, astronomy, or meteorology. Earth science educators struggle to gain an equal footing in K-12 education with life and physical science teachers, and only $7 \%$ of high school students take ESS courses (Lewis \& Baker, 2010). For the past 26 years, the percentage of high school students taking Earth science has never surpassed 25\% (Gonzales, 2009, 2011). In 2007, only seven states required ESS in their high school science curriculum, though 25 states recommended ESS as a part of the high school science curriculum (Gonzales, 2009, 2011). In middle school, trends over the past 18 years show that only $11 \%$ - 15\% of students take a specific Earth science course, though this statistic does not count integrated science courses with an Earth science component (Gonzales, 2009, 2011).

In an American Geosciences Institute (AGI) report released in 2011, only 21\% of high school science teachers were teaching Earth science (Gonzales, 2011). In addition, only 3\% of high school science teachers had their highest degree in the geosciences (Gonzales, 2011). According to this report, AGI had contacted 262 four-year colleges and universities to determine whether or not they accept a high school Earth science course for admission (Benbow, 2011). At least three schools, both public and private, were contacted in each state (Benbow, 2011). As of May 8, 2011, two hundred twenty six schools responded and $77 \%$ of the surveyed institutions accepted high school Earth science courses, but there can be conditions on that acceptance. For example, some institutions required an Earth science course with a lab course, but did not specify what made it a lab course (Benbow, 2011). Only 5.8 percent of schools responding to the survey said they do not accept an Earth science course for college admission (Benbow, 2011). Some reasons listed for not accepting Earth science were that there was no Advanced Placement exam and that Earth science is not as rigorous as biology, chemistry, and physics (Benbow, 2011).

The absence of ESS education in middle school and high school is a major problem considering that many of today's political issues revolve around Earth science. To underscore this idea, The Geological Society of America's (GSA) position statement reads:

Basic knowledge of Earth science is essential to meeting the environmental challenges and natural resource limitations of the twenty-first century. It is critical that Earth-science education begins at the kindergarten level and includes advanced offerings at the secondary school level, and that highly qualified Earth-science teachers provide the instruction. GSA recommends that the study of Earth science be an integral component of science education in public and private schools at all levels, from kindergarten through twelfth grade (Geological Society of America, 2011).

The low number of students in the Earth sciences is at odds with the National Science and Education Standards (National Research Council, 1996, 2012) that gives equal emphasis to ESS as part of a national vision of scientific literacy (Lewis \& Baker, 2010).

Previous studies of ESS education in the United States mainly focus on content; perhaps two of the most important questions for ESS education are: (1) Why are only 7\% of students in high school taking ESS, and (2) Why aren't more teachers teaching ESS as part of the high school science curriculum? Prologue to these fundamental questions is, why students and teachers do not hold ESS to the same standards as physics, chemistry and math (Lewis \& Baker, 2010). It was the goal of this study to complete an exploratory investigation into the attitudes of teachers and students regarding ESS education in middle school and high school within a specific locale.

\section{Research Questions}

The purpose of this investigation was to analyze teacher and student perceptions of Earth science and its educational value in secondary schools. Perceptions of teachers and students were delimited with a) the importance of ESS in the high school curriculum and b) general interest in ESS. Educational value refers to a) students' and teachers' judgments of the importance of ESS compared to physics, chemistry, and biology and b) perceived rigor of ESS (depth and breadth) compared to physics, chemistry, and biology. More specifically, the research questions for this study were (1) Do Earth science teachers and non-Earth science teachers differ on their perceptions toward Earth science and its educational value in secondary schools? (2) Do teachers with varying number of college credit hours of Earth science relate to differing attitudes toward Earth science? (3) Do attitudes toward Earth science differ between teachers and students? 


\section{Theoretical Framework}

The stereotypical view of Earth and space sciences is that these subjects are less rigorous than biology, chemistry, and physics (Lewis \& Baker, 2010). This attitude further reinforces misconceptions about the breadth, depth, and rigor of the geosciences; and merely 7\% of high school students are taking ESS in high school (Lewis \& Baker, 2010). Dodick \& Orion (2003) state possible reasons for the lack of ESS in pre-college education may be that, “...geology has often been portrayed as a 'derivative' science whose methodology and logic were provided by the physical sciences" (p. 198). Indeed, geology is often thought of as an "impure" science, because it is a science that applies biology, physics, and chemistry in order to develop its principles. However, that certainly should not devalue geology. On the contrary, it gives students a chance to apply their knowledge of the "pure" sciences...

Other reasons for ESS's absence in secondary schools may be due to attitudes among scientists and teachers that “...geology...has many practical and theoretical limitations...such as incompleteness of the stratigraphic and fossil record, lack of experimental verification and the nature of 'deep time', which precludes direct observation,” (Dodick \& Orion, 2003: p. 198). The difficulty of experimental verification and the monumentally slow pace of geologic processes should not be a factor in deciding whether to teach ESS. "By neglecting this discipline [Earth science]...educators inadvertently deprive students of a unique system of scientific thinking...” (Dodick \& Orion, 2003: p. 198).

King (2001) conducted a survey of Earth science teachers in Britain that focused on a) gauging teacherperception of the effectiveness of their Earth science teaching, b) identifying issues that might affect teacher effectiveness, and c) gathering background data that could help improve any ineffectiveness of ESS teaching. The results of the study indicated that only $1 \%$ of all respondents listed geology as their main teaching subject. Most teachers had integrated Earth science into biology, chemistry, or physics (King, 2001). Less than 1\% of surveyed ESS teachers had a degree in Earth science, had a degree that contained an Earth science component, or had a degree that contained some Earth science content (King, 2001). Over 80\% of Earth science teachers reported that their degree either contained no Earth science, and that they learned very little to no Earth science in their pre-service education (King, 2001). The low number of ESS teachers with actual Earth science backgrounds frustrated many teachers (King, 2001). The overall conclusion to this study indicated that teachers' perceptions of ESS were very negative and these negative attitudes, along with the low educational value teachers gave to Earth science, appeared to be passed on to ESS students.

The aforementioned studies all share common themes such as a lack of teacher preparation in Earth science and a lack of teacher interest, which leads to poor student attitudes. It was the goal of this exploratory study to evaluate student and teacher attitudes regarding ESS and to investigate this beginning with a local perspective.

\section{Research Methodology}

\subsection{Sample}

One hundred thirty-two science teachers from 8 middle schools and 5 high schools in urban and suburban areas of a mid western state were asked to complete the Earth Science Teacher Survey. One hundred fifty students taking science in one of those same high schools were asked to complete the Earth Science Student Survey. Thirty-nine teachers and 46 students returned the completed surveys. The return rate of the surveys was $29.5 \%$ for teachers and $30.7 \%$ for students. Teachers included those who teach science subjects including, but not limited to, biology, chemistry, physics, environmental science, and Earth science (including concepts in geology, oceanography, meteorology, or astronomy).

This state does not require ESS to be taught in high school. However, courses such as Astronomy and Environmental Science are often offered in the state's high schools. Middle schools incorporate ESS concepts/content within their general science courses. In grade 6, students are supposed to be taught a) the structures of the Earth; b) the solar system; c) that Earth has four main interacting systems including the atmosphere, hydrosphere, biosphere, and geosphere (Table 1); d) a unit on the water cycle; and d) that the sun provides energy to maintain life. In grade 7 , students are to be taught a) that atmospheric movement affects weather and climate, and the differences between weather and climate and b) about solar system interactions that cause days, years, phases of the moon, eclipses, and seasons. Grade 8 students are taught a) that Earth's major landforms are the result of crustal deformation, volcanic eruptions, deposition of sediments, weathering and erosion; b) the rock cycle and 
Table 1. Earth science standards for Oklahoma.

\begin{tabular}{|c|c|c|c|}
\hline Grade 6 & Grade 7 & Grade 8 & High School \\
\hline $\begin{array}{l}\text { Structure of the Earth and the } \\
\text { Solar System }\end{array}$ & $\begin{array}{l}\text { Atmospheric movement affects } \\
\text { weather and climate }\end{array}$ & $\begin{array}{l}\text { Earth's major landforms are the } \\
\text { result of crustal deformation, } \\
\text { volcanic eruptions, deposition of } \\
\text { sediments, weathering and erosion }\end{array}$ & $\begin{array}{l}\text { No set standards for Earth science. } \\
\text { Earth science is not a required } \\
\text { course. }\end{array}$ \\
\hline $\begin{array}{l}\text { Earth has four main interacting } \\
\text { systems including the atmosphere, } \\
\text { the hydrosphere, biosphere, and } \\
\text { the geosphere }\end{array}$ & $\begin{array}{l}\text { Solar system interactions cause } \\
\text { days, years, phases of the moon, } \\
\text { eclipses, and seasons }\end{array}$ & The Rock Cycle & \\
\hline Water Cycle is driven by the Sun & & $\begin{array}{l}\text { Geologic time and how fossils } \\
\text { provide evidence of past life and } \\
\text { ancient environmental conditions }\end{array}$ & \\
\hline
\end{tabular}

conservation of matter; and c) geologic time and how fossils provide evidence of past life and ancient environmental conditions (Oklahoma State Department of Education, 2012).

\subsection{Instruments}

The instruments for the study were the Earth Science Teacher Survey (ESTS) (Table 2) and the Earth Science Student Survey (ESSS) (Table 3). Each questionnaire was derived from the questionnaire of King (2001) and modified by rewording some questions to be more generalized, as well as, adding questions that are specific to the quests of this study.

The teacher and student questionnaires had 14 questions each and responses were based on a Likert scale with 0 being the lowest and 5 being the highest. An option of not applicable (N/A) was also available. For the ESTS, questions 9 - 14 were to be answered by only Earth science teachers. Teachers had as much time as needed to complete the questionnaire. Each teacher and student also completed a biography page with questions about age, gender, grade level, and types of science they have taught or have taken. The instruments were administered during September and October of 2010.

A panel of research scientists, a science educator, and a group of middle school science teachers evaluated the student and teacher questionnaires and deemed them to be valid instruments. A pilot study determined the reliability of the teacher and student survey. The teacher questionnaire was administered to 26 secondary school science teachers within the state of the study and to 44 students of these teachers. Surveys were completed voluntarily and anonymously.

The data collected from the teacher survey were evaluated for internal consistency reliability using Cronbach's alpha. The reliability coefficient for the Earth Science Teacher Survey (ESTS) was determined to be 0.811 . The data collected from the student survey were also evaluated for internal consistency reliability using Cronbach's alpha. The reliability for the Earth Science Student Survey (ESSS) was determined to be 0.851 .

\subsection{Data Collection and Analyses}

Teachers and students were asked for their consent to participate in the research study. Teachers were mailed information sheets and questionnaires and asked to return the surveys by mail. Students were asked in person to have their parents sign their consent forms; they had one week to return consent forms. Students and teachers complete surveys in about 10 minutes. Students returned their surveys to the researcher and teachers mailed their surveys to the researcher in secured envelopes.

Descriptive statistics were subjected to statistical analyses to see if observed differences in the data were significant. A two-way ANOVA with weighted means (Table 4 and Table 5) was completed to answer the research questions related to Earth science teachers' credit hours of ESS in college and teachers' perceptions of ESS and its educational value (with perceptions and educational value attributing to overall attitudes). A t-test (Table 6) was used to answer the research question comparing students' and teachers' views towards Earth science. The t-test assumed unequal variances and compared students' views and teachers' views for enjoyment level of learning and teaching Earth science; importance of Earth science in college; importance of Earth science for students' future careers; Earth science's importance compared to physics, chemistry, and biology; and Earth science's importance in secondary education for preparing students to be knowledgeable citizens of the United States. 
Table 2. Earth Science Teacher Survey questions and percentage answered on a Likert scale for each question. Questions 9 14 were answered only by Earth science teachers.

\begin{tabular}{|c|c|c|c|c|c|c|c|}
\hline Question & N/A & 0 & 1 & 2 & 3 & 4 & 5 \\
\hline 1. What is your background knowledge of earth science? & $2.6 \%$ & $0.0 \%$ & $12.8 \%$ & $18.0 \%$ & $30.8 \%$ & $30.8 \%$ & $5.1 \%$ \\
\hline 2. How confident do you feel teaching earth science? & $5.1 \%$ & $5.1 \%$ & $12.8 \%$ & $15.4 \%$ & $15.4 \%$ & $25.6 \%$ & $20.5 \%$ \\
\hline 3. How much do you enjoy teaching earth science? & $20.5 \%$ & $5.1 \%$ & $18.0 \%$ & $5.1 \%$ & $15.4 \%$ & $12.8 \%$ & $23.1 \%$ \\
\hline $\begin{array}{l}\text { 4. What do you think is the overall importance of earth } \\
\text { science compared to physics, chemistry, and biology? }\end{array}$ & $0.0 \%$ & $0.0 \%$ & $7.7 \%$ & $28.2 \%$ & $28.2 \%$ & $23.1 \%$ & $12.8 \%$ \\
\hline $\begin{array}{l}\text { 5. How would you rank the rigor (depth and breadth) of } \\
\text { earth science compared to physics, chemistry, and biology? }\end{array}$ & $3.3 \%$ & $6.7 \%$ & $26.7 \%$ & $23.3 \%$ & $36.7 \%$ & $30.0 \%$ & $3.3 \%$ \\
\hline $\begin{array}{l}\text { 6. How important is earth science in secondary school } \\
\text { education to prepare students for their careers? }\end{array}$ & $2.6 \%$ & $2.6 \%$ & $20.5 \%$ & $28.2 \%$ & $23.1 \%$ & $20.5 \%$ & $2.6 \%$ \\
\hline $\begin{array}{l}\text { 7. How important is earth science in secondary school } \\
\text { education to prepare students for college? }\end{array}$ & $2.6 \%$ & $0.0 \%$ & $20.5 \%$ & $23.1 \%$ & $33.3 \%$ & $18.0 \%$ & $2.6 \%$ \\
\hline $\begin{array}{l}\text { 8. How important is earth science in secondary school } \\
\text { education to prepare students to be knowledgeable citizens } \\
\text { of the United States? }\end{array}$ & $0.0 \%$ & $0.0 \%$ & $12.8 \%$ & $15.4 \%$ & $33.3 \%$ & $28.2 \%$ & $10.3 \%$ \\
\hline $\begin{array}{l}\text { 9. What do you think is the level of interest of the students } \\
\text { regarding the earth science that you teach? }\end{array}$ & $0.0 \%$ & $0.0 \%$ & $0.0 \%$ & $0.0 \%$ & $58.3 \%$ & $41.7 \%$ & $0.0 \%$ \\
\hline $\begin{array}{l}\text { 10. How important is earth science for understanding issues } \\
\text { like energy resources, climate change, and the absence of } \\
\text { fresh water in many parts of the world? }\end{array}$ & $0.0 \%$ & $0.0 \%$ & $8.3 \%$ & $8.3 \%$ & $41.7 \%$ & $41.7 \%$ & $0.0 \%$ \\
\hline $\begin{array}{l}\text { 11. How much laboratory work do you use when teaching } \\
\text { earth science topics? }(0=\text { No labs, } 5=3 \text { or more labs per } \\
\text { week) }\end{array}$ & $0.0 \%$ & $16.7 \%$ & $8.3 \%$ & $16.7 \%$ & $8.3 \%$ & $25.0 \%$ & $25.0 \%$ \\
\hline $\begin{array}{l}\text { 12. Per semester, how much fieldwork (i.e. a fieldtrip) is } \\
\text { included in the earth science you teach? ( } 5 \text { = one full day, } 0 \\
\text { = none) }\end{array}$ & $0.0 \%$ & $58.3 \%$ & $0.0 \%$ & $0.0 \%$ & $25.0 \%$ & $8.3 \%$ & $8.3 \%$ \\
\hline $\begin{array}{l}\text { 13. How comfortable are you with using the learning cycle } \\
\text { to teach earth science? }\end{array}$ & $8.3 \%$ & $8.3 \%$ & $0.0 \%$ & $0.0 \%$ & $0.0 \%$ & $41.7 \%$ & $41.7 \%$ \\
\hline $\begin{array}{l}\text { 14. Do you think that a solid understanding of earth science } \\
\text { topics is essential to understanding today's geopolitical } \\
\text { conflicts such as the energy crisis, water crisis, and climate } \\
\text { change? }\end{array}$ & $0.0 \%$ & $0.0 \%$ & $0.0 \%$ & $0.0 \%$ & $0.0 \%$ & $50.0 \%$ & $50.0 \%$ \\
\hline
\end{tabular}

\subsection{Limitations of the Study}

Since ESS is not a large part of the curriculum throughout the study-state, it was difficult to locate ESS teachers to participate. However the 12 ESS teachers surveyed made up 31\% of the returned surveys and were therefore a meaningful part of the research sample. Sample sizes of students and teachers were not as large as anticipated and came from two different school districts and therefore represent a limited region. However, because the state is considered an oil-rich state with much of its economy supported by oil and natural gas companies, it is an especially important regional picture since Earth science plays a larger role than it may in other states.

\section{Results}

\subsection{Teacher Survey Results}

The primary teaching assignments of the teachers who answered the survey were biology, Earth science, environmental science, physics, chemistry, and/or physical science. Of 39 teachers, 16 (41\%) were males and 23 (59\%) were females. Only one teacher had a degree in Earth science, but said he did not teach ESS. The average age-range of teachers surveyed was 31 - 40 years. Reported teaching experience ranged from 3 months to 39 years with an average of 12.7 years. Respondents who teach Earth science had 0 - 30 credit hours of Earth science in college and an average of 10 credit hours. Of the 12 teachers who said their primary teaching subject was Earth science, 7 were high school teachers and 5 were middle school teachers.

About $62 \%$ of teachers said they had an average to above average background knowledge of Earth science 
Table 3. Earth science student survey questions and percentage answered on a Likert scale for each question.

\begin{tabular}{|c|c|c|c|c|c|c|c|}
\hline Question & N/A & 0 & 1 & 2 & 3 & 4 & 5 \\
\hline $\begin{array}{l}\text { 1. Rate what you know about earth science on a scale of } 0 \text { to } 5 \\
(0=\text { You don't know anything, } 5=\text { You know quite a bit) Earth } \\
\text { science topics are geology, oceanography, meteorology, or } \\
\text { astronomy. }\end{array}$ & $0.0 \%$ & $4.3 \%$ & $13.0 \%$ & $17.4 \%$ & $47.2 \%$ & $13.0 \%$ & $4.3 \%$ \\
\hline 2. How much do you enjoy learning about earth science topics? & $0.0 \%$ & $6.5 \%$ & $8.7 \%$ & $13.0 \%$ & $21.7 \%$ & $28.3 \%$ & $21.7 \%$ \\
\hline $\begin{array}{l}\text { 3. How important is earth science compared to physics, } \\
\text { chemistry, and biology? }\end{array}$ & $2.2 \%$ & $8.7 \%$ & $6.5 \%$ & $17.4 \%$ & $34.8 \%$ & $17.4 \%$ & $13.0 \%$ \\
\hline $\begin{array}{l}\text { 4. How would you rank the difficulty of earth science compared } \\
\text { to physics, chemistry, and biology? }\end{array}$ & $6.5 \%$ & $4.3 \%$ & $17.4 \%$ & $26.1 \%$ & $26.1 \%$ & $17.4 \%$ & $2.2 \%$ \\
\hline $\begin{array}{l}\text { 5. How important is it to take earth science in middle school } \\
\text { and/or high school to prepare you for your future job? }\end{array}$ & $2.2 \%$ & $8.7 \%$ & $6.5 \%$ & $10.9 \%$ & $43.5 \%$ & $6.5 \%$ & $21.7 \%$ \\
\hline $\begin{array}{l}\text { 6. How important is it to take earth science in middle school } \\
\text { and/or high school to prepare you for college? }\end{array}$ & $0.0 \%$ & $8.7 \%$ & $2.2 \%$ & $15.2 \%$ & $26.1 \%$ & $37.0 \%$ & $10.9 \%$ \\
\hline $\begin{array}{l}\text { 7. How important is it to take earth science in middle school } \\
\text { and/or high school to prepare you to be a well-informed citizen } \\
\text { of the United States? }\end{array}$ & $2.2 \%$ & $8.7 \%$ & $6.5 \%$ & $13.0 \%$ & $28.3 \%$ & $19.6 \%$ & $21.7 \%$ \\
\hline 8. What is your level of interest in earth science? & $2.2 \%$ & $8.7 \%$ & $8.7 \%$ & $8.7 \%$ & $28.3 \%$ & $26.1 \%$ & $17.4 \%$ \\
\hline $\begin{array}{l}\text { 9. What grade do you usually earn when you learn about earth } \\
\text { science topics? ( } 5=\mathrm{A}, 4=\mathrm{B}, 3=\mathrm{C}, 2=\mathrm{D}, 1=\mathrm{F}, 0=\text { Don't } \\
\text { know, N/A = Not Applicable). }\end{array}$ & $2.2 \%$ & $8.7 \%$ & $0.0 \%$ & $2.2 \%$ & $10.9 \%$ & $17.4 \%$ & $58.7 \%$ \\
\hline $\begin{array}{l}\text { 10. How important is earth science for understanding issues like } \\
\text { energy resources, climate change, and the absence of fresh } \\
\text { water in many parts of the world? }\end{array}$ & $0.0 \%$ & $2.2 \%$ & $4.3 \%$ & $4.3 \%$ & $6.5 \%$ & $32.6 \%$ & $50.0 \%$ \\
\hline $\begin{array}{l}\text { 11. Do you think that earth science topics are easy to } \\
\text { understand? }\end{array}$ & $2.2 \%$ & $0.0 \%$ & $4.3 \%$ & $2.2 \%$ & $30.4 \%$ & $39.1 \%$ & $21.7 \%$ \\
\hline $\begin{array}{l}\text { 12. Do you think that more laboratory work and/or field trips } \\
\text { would make earth science topics easier to understand? }\end{array}$ & $2.2 \%$ & $0.0 \%$ & $4.3 \%$ & $4.3 \%$ & $15.2 \%$ & $32.6 \%$ & $41.3 \%$ \\
\hline $\begin{array}{l}\text { 13. Compared to physics, chemistry, and biology, how } \\
\text { hands-on are lessons involving earth science topics? }(0=\text { not } \\
\text { hands-on at all, } 5=\text { Very hands-on). }\end{array}$ & $6.5 \%$ & $0.0 \%$ & $13.0 \%$ & $4.3 \%$ & $26.1 \%$ & $45.7 \%$ & $4.3 \%$ \\
\hline $\begin{array}{l}\text { 14. After taking earth science, how likely are you to consider a } \\
\text { career in the earth sciences? Careers include geologists (study } \\
\text { the earth), paleontologists (study fossils), meteorologists (study } \\
\text { weather), astronomers (study space), engineers (design and } \\
\text { build things), park rangers (conserve resources), and teachers. }\end{array}$ & $2.2 \%$ & $15.2 \%$ & $2.2 \%$ & $17.4 \%$ & $32.6 \%$ & $17.4 \%$ & $13.0 \%$ \\
\hline
\end{tabular}

with only 5\% saying they had a vast amount of Earth science knowledge. Fewer than half of teachers reported that they felt confident or very confident teaching Earth science and only 36\% said they enjoy or highly enjoy teaching Earth science.

Approximately 23\% of teachers responding to the survey said they thought Earth science is as important as physics, chemistry, and biology, and only 13\% thought Earth science is very important. With regards to Earth science's rigor (depth and breadth), about 30\% of teachers ranked it as similar to physics, chemistry, and biology, and only 3\% said Earth science was equally difficult as physics, chemistry, and biology.

Twenty-three percent of surveyed teachers reported that ESS was important or very important for secondary school education to prepare students for their future careers; and 20\% noted that Earth science was important or very important in secondary school education to prepare students for college. This contrasted slightly with teachers thinking that Earth science in secondary school prepared students to be knowledgeable citizens of the United States, with about 39\% of surveyed teachers saying it was important or very important.

Figure 1 lists the percentage answered for questions 1 - 8 with only data from teachers who said they teach Earth science. Figure 2 shows the percentage answered for questions 1 - 8 for teachers who said they did not teach Earth science. There were major differences between these two groups in their responses. First, Earth science teachers ranked their knowledge of the subject as much higher. Second, 83\% of Earth science teachers said they felt confident or very confident teaching Earth science compared to $29 \%$ of teachers who do not teach ESS. There was also a dramatic difference in the enjoyment level of teaching ESS with $67 \%$ of Earth science 
Table 4. ANOVA weighted mean results of teacher survey: perceptions of earth science.

\begin{tabular}{|c|c|c|c|c|c|}
\hline \multicolumn{6}{|c|}{ Question 1: What is your background in earth science? } \\
\hline Source & SS & $\mathrm{df}$ & MS & $\mathrm{F}$ & $\mathrm{P}$ \\
\hline Rows (ESS vs. Non-ESS Teachers) & 6.52 & 1 & 6.52 & 8.55 & 0.0063 \\
\hline Columns $(0-6,7-12$, or $13+$ credit hours of ESS) & 13.6 & 2 & 6.8 & 8.91 & 0.0008 \\
\hline Rows $\times$ Columns & 2.44 & 2 & 1.22 & 1.6 & 0.2176 \\
\hline Error & 24.41 & 32 & 0.76 & & \\
\hline Total & 46.97 & 37 & & & \\
\hline \multicolumn{6}{|c|}{ Question 2: How confident do you feel teaching earth science? } \\
\hline Source & SS & df & MS & $\mathrm{F}$ & $\mathrm{P}$ \\
\hline Rows (ESS vs. Non-ESS Teachers) & 23.16 & 1 & 23.16 & 20.12 & 0.0001 \\
\hline Columns $(0-6,7-12$, or $13+$ credit hours of ESS) & 18.08 & 2 & 9.04 & 7.85 & 0.0017 \\
\hline Rows $\times$ Columns & 8.65 & 2 & 4.33 & 3.76 & 0.0345 \\
\hline Error & 35.68 & 31 & 1.15 & & \\
\hline Total & 85.57 & 36 & & & \\
\hline \multicolumn{6}{|c|}{ Question 3: How much do you enjoy teaching earth science? } \\
\hline Source & SS & $\mathrm{df}$ & MS & $\mathrm{F}$ & $\mathrm{P}$ \\
\hline Rows (ESS vs. Non-ESS Teachers) & 18.34 & 1 & 18.34 & 9.62 & 0.0047 \\
\hline Columns $(0-6,7-12$, or $13+$ credit hours of ESS) & 16.24 & 2 & 8.12 & 4.26 & 0.0256 \\
\hline Rows $\times$ Columns & 6.71 & 2 & 3.36 & 1.76 & 0.1927 \\
\hline Error & 47.68 & 25 & 1.91 & & \\
\hline Total & 88.97 & 30 & & & \\
\hline \multicolumn{6}{|c|}{ Question 5: How would you rank the rigor (depth and breadth) of earth science compared to physics, chemistry, and biology? } \\
\hline Source & SS & df & MS & F & $\mathrm{P}$ \\
\hline Rows (ESS vs. Non-ESS Teachers) & 0.27 & 1 & 0.27 & 0.15 & 0.7012 \\
\hline Columns $(0-6,7-12$, or $13+$ credit hours of ESS $)$ & 4.51 & 2 & 2.26 & 1.28 & 0.2923 \\
\hline Rows $\times$ Columns & 0 & 2 & 0 & 0 & 1 \\
\hline Error & 54.48 & 31 & 1.76 & & \\
\hline Total & 59.19 & 36 & & & \\
\hline
\end{tabular}

teachers saying they enjoy or highly enjoy teaching Earth science, and only 22\% of non-Earth science teachers saying they enjoy or highly enjoy teaching Earth science. A smaller difference is seen for whether teachers think the overall importance of Earth science is similar to physics, chemistry, and biology. Around 25\% of both ESS teachers and non-ESS teachers said that Earth science's rigor is average to slightly above average compared to physics, chemistry, and biology. Also, similar percentages of ESS teachers and non-ESS teachers reported that taking Earth science in middle school and/or high school was important to prepare students for their careers and for college.

Questions 1 - 8 on the teacher survey were also divided by the number of ESS credit hours teachers completed in college. Figure 3 shows the results for teachers who have taken 0 - 6 credit hours of Earth science, Figure 4 shows the results for teachers who have taken 7 - 12 credit hours of Earth science, and Figure 5 shows the results for teachers who have taken 13 or more credit hours of Earth science in college. There were 17 teachers who had 0 - 6 credit hours of Earth science, 17 teachers who had 7 - 12 credit hours of Earth science, and 5 teachers who had 13 or more credit hours of Earth science. The results clearly show that teachers who had more credit hours of Earth science in college ranked their knowledge of Earth science higher. Also, teachers who had more credit hours of Earth science felt more confident teaching ESS. Enjoyment of teaching Earth science also increased with the number of credit hours taken in college.

A greater difference could be seen for the rigor of Earth science as compared to physics, chemistry, and biology. Only $18 \%$ of teachers with $0-6$ credit hours of Earth science and $24 \%$ of teachers with $7-12$ credit hours 
Table 5. ANOVA weighted mean results of teacher survey: educational value of earth science.

\begin{tabular}{|c|c|c|c|c|c|}
\hline \multicolumn{6}{|c|}{ Question 4: What do you think is the overall importance of earth science compared to physics, chemistry, and biology? } \\
\hline Source & SS & df & MS & $\mathrm{F}$ & $\mathrm{P}$ \\
\hline Rows (ESS vs. Non-ESS Teachers) & 1.38 & 1 & 1.38 & 0.94 & 0.3393 \\
\hline Columns (0 - 6, 7 - 12, or $13+$ credit hours of ESS) & 2.2 & 2 & 1.1 & 0.75 & 0.4802 \\
\hline Rows $\times$ Columns & 0.07 & 2 & 0.04 & 0.02 & 0.9802 \\
\hline Error & 48.25 & 33 & 1.46 & & \\
\hline Total & 51.9 & 38 & & & \\
\hline \multicolumn{6}{|c|}{ Question 6: How important is earth science in secondary school education to prepare students for their careers? } \\
\hline Source & SS & df & MS & $\mathrm{F}$ & $\mathrm{P}$ \\
\hline Rows (ESS vs. Non-ESS Teachers) & 2.27 & 1 & 2.27 & 1.49 & 0.2311 \\
\hline Columns ( 0 - 6, $7-12$, or $13+$ credit hours of ESS) & 2.31 & 2 & 1.16 & 0.76 & 0.4759 \\
\hline Rows $\times$ Columns & 0 & 1 & 0 & 0 & 1 \\
\hline Error & 48.9 & 32 & 1.53 & & \\
\hline Total & 53.47 & 37 & & & \\
\hline \multicolumn{6}{|c|}{ Question 7: How important is earth science in secondary school education to prepare students for college? } \\
\hline Source & SS & df & MS & $\mathrm{F}$ & $\mathrm{P}$ \\
\hline Rows (ESS vs. Non-ESS Teachers) & 6.06 & 1 & 6.06 & 5.34 & 0.0274 \\
\hline Columns (0 - 6, 7 - 12, or $13+$ credit hours of ESS) & 3.56 & 2 & 1.78 & 1.57 & 0.2237 \\
\hline Rows $\times$ Columns & 0 & 2 & 0 & 0 & 1 \\
\hline Error & 36.31 & 32 & 1.13 & & \\
\hline Total & 45.26 & 37 & & & \\
\hline \multicolumn{6}{|c|}{$\begin{array}{l}\text { Question 8: How important is earth science in secondary school education to prepare students to be knowledgeable citizens of th } \\
\text { United States? }\end{array}$} \\
\hline Source & SS & $\mathrm{df}$ & MS & $\mathrm{F}$ & $\mathrm{P}$ \\
\hline Rows (ESS vs. Non-ESS Teachers) & 5.03 & 1 & 5.03 & 3.4 & 0.0742 \\
\hline Columns (0 - 6, 7 - 12, or $13+$ credit hours of ESS) & 0.32 & 2 & 0.16 & 0.11 & 0.8962 \\
\hline Rows $\times$ Columns & 0.12 & 2 & 0.06 & 0.04 & 0.9608 \\
\hline Error & 48.89 & 33 & 1.48 & & \\
\hline Total & 54.36 & 38 & & & \\
\hline
\end{tabular}

Table 6. T-test results: comparing teachers to students.

\begin{tabular}{|c|c|c|c|}
\hline \multicolumn{4}{|l|}{ t-test: Two-Sample Assuming Unequal Variances } \\
\hline Variable & Groups Tested & df & P (two-tail) \\
\hline Enjoyment Teaching/Learning about ESS & Science Teacher/Science Student & 56 & 0.6752 \\
\hline Importance of ESS for College & Science Teacher/Science Student & 81 & 0.0206 \\
\hline Importance of ESS for Students’ Future Career & Science Teacher/Science Student & 79 & 0.1126 \\
\hline Importance of ESS Compared to Physics, Chemistry, and Biology & Science Teacher/Science Student & 78 & 0.0359 \\
\hline Importance of ESS to be Knowledgeable Citizens of the United States & Science Teacher/Science Student & 80 & 0.7192 \\
\hline
\end{tabular}

thought that Earth science had a similar or very similar rigor (depth and breadth) compared to physics, chemistry, and biology. However, $40 \%$ of teachers with 13 or more credit hours of Earth science thought it was of similar rigor.

Only $12 \%$ of teachers with 0 - 6 credit hours of Earth science thought that Earth science was important or very important in secondary school for students' future careers. About 30\% of teachers with 7 - 12 credit hours of Earth science and $40 \%$ of teachers with 13 or more credit hours thought that Earth science was important or 


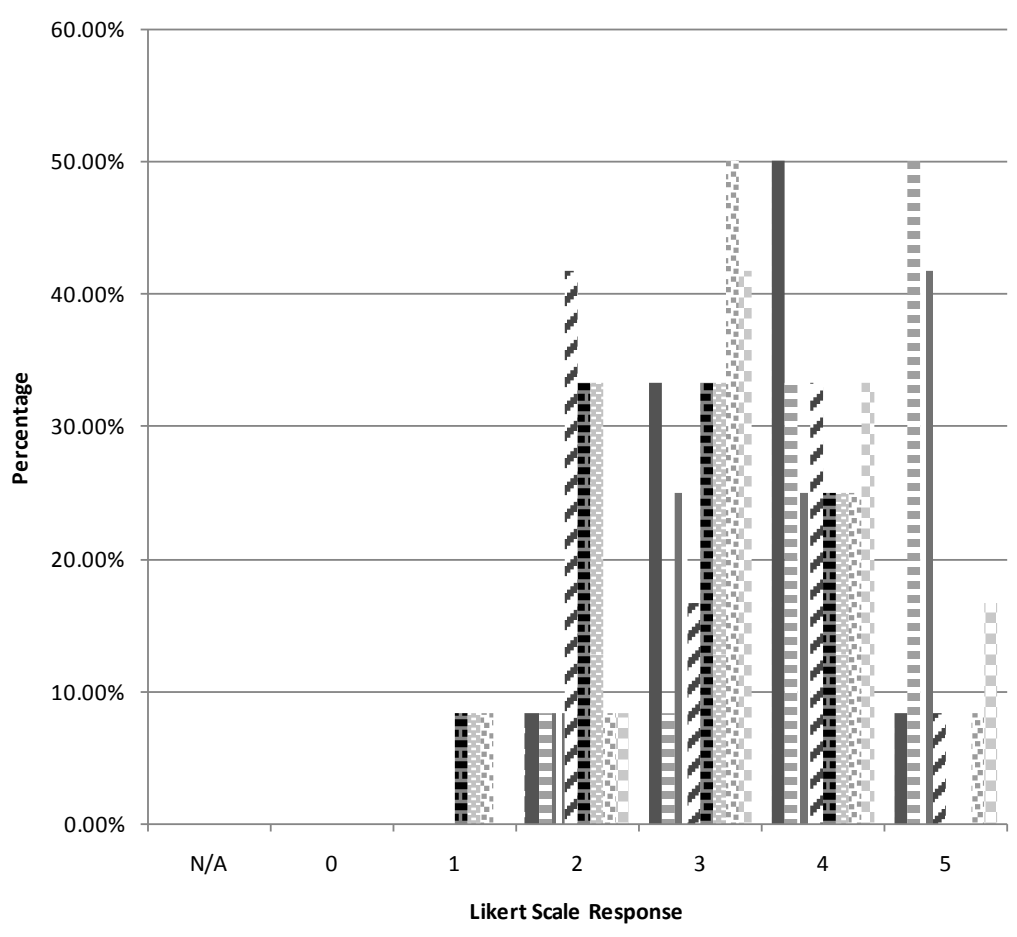

D1. What is your background knowledge of earth science?

$=2$. How confident do you feel teaching earth science?

I 3. How much do you enjoy teaching earth science?

F. What do you think is the overall importance of earth science compared to physics, chemistry, and biology?

E. How would you rank the rigor (depth and breadth) of earth science compared to physics, chemistry, and biology?

6. How important is earth science in secondary school education to prepare students for their careers?

Fi 7. How important is earth science in secondary school education to prepare students for college?

8. How important is earth science in secondary school education to prepare students to be knowledgeable citizens of the United States?

Figure 1. Earth science teacher survey results for questions 1 - 8 with only data from teachers who said they teach earth science.

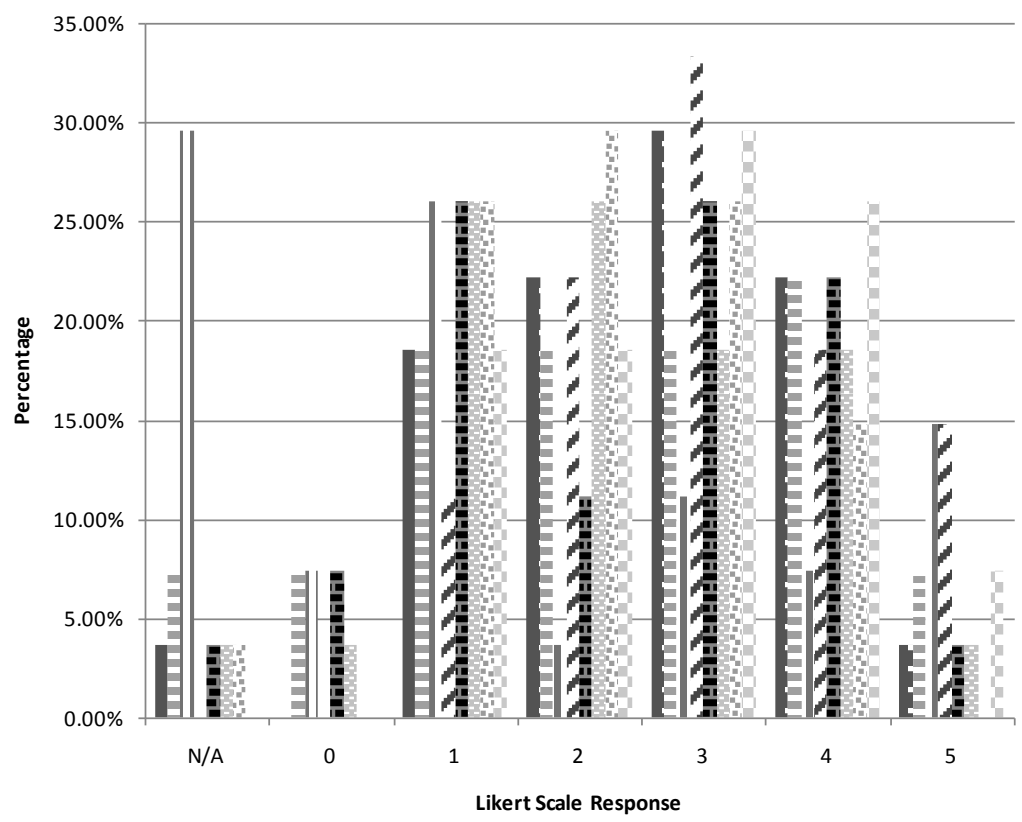

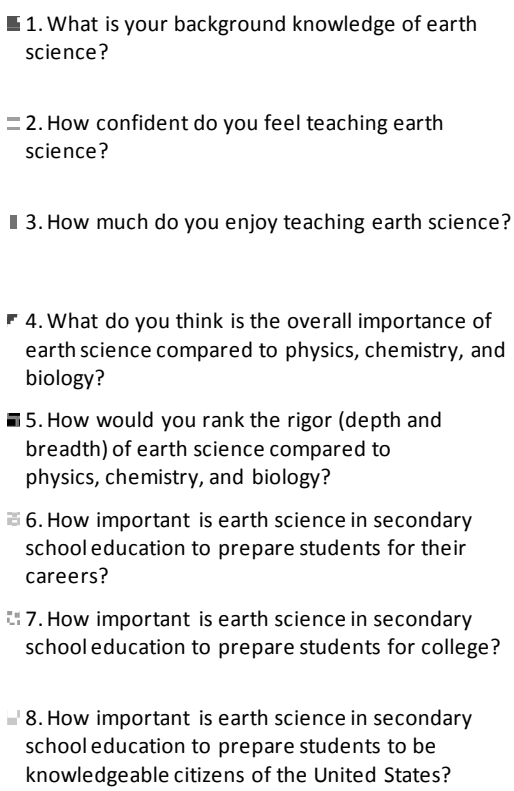

4. What do you think is the overall importance of earth science compared to physics, chemistry, and biology?

च 5. How would you rank the rigor (depth and breadth) of earth science compared to physics, chemistry, and biology?

6. How important is earth science in secondary school education to prepare students for their careers?

7. How important is earth science in secondary school education to prepare students for college?

8. How important is earth science in secondary school education to prepare students to be knowledgeable citizens of the United States?

Figure 2. Earth science teacher survey results for questions 1 - 8 with only data from teachers who said they do not teach Earth science.

very important to take in secondary school to prepare for future careers. When asked if Earth science was important to take in secondary school to prepare students for college, $12 \%$ of teachers with 0 - 6 credit hours of Earth science said that it was important or very important, about $24 \%$ of teachers with 7 - 12 credit hours said it was important or very important, and $40 \%$ of teachers with 13 or more credit hours said it was important or very important. 


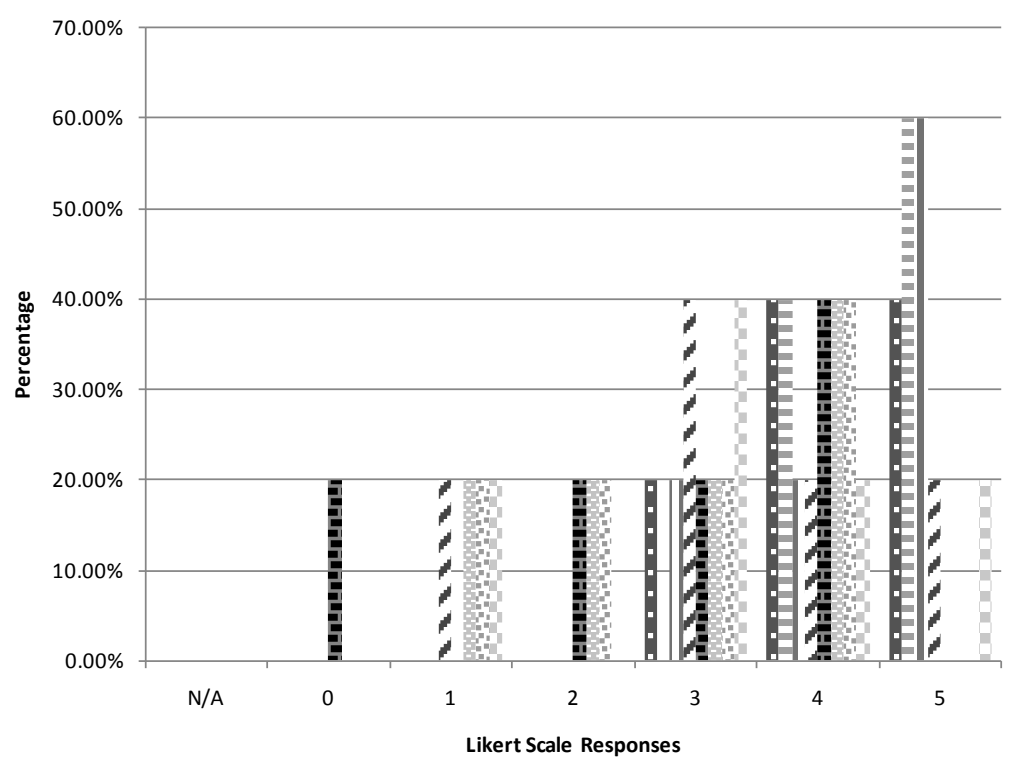
E1. What is your background knowledge of earth science?
$=2$. How confident do you feel teaching earth science?
I 3. How much do you enjoy teaching earth science?
4. What do you think is the overall importance of earth science compared to physics, chemistry, and biology?
$\mathbf{m}$ 5. How would you rank the rigor (depth and breadth) of earth science compared to physics, chemistry, and biology?
6 . How important is earth science in secondary school education to prepare students for their careers?
7. How important is earth science in secondary school education to prepare students for college?
8. How important is earth science in secondary school education to prepare students to be knowledgeable citizens of the United States?

Figure 3. Earth science teacher survey results from teachers who have taken 0 - 6 credit hours of Earth science in college.
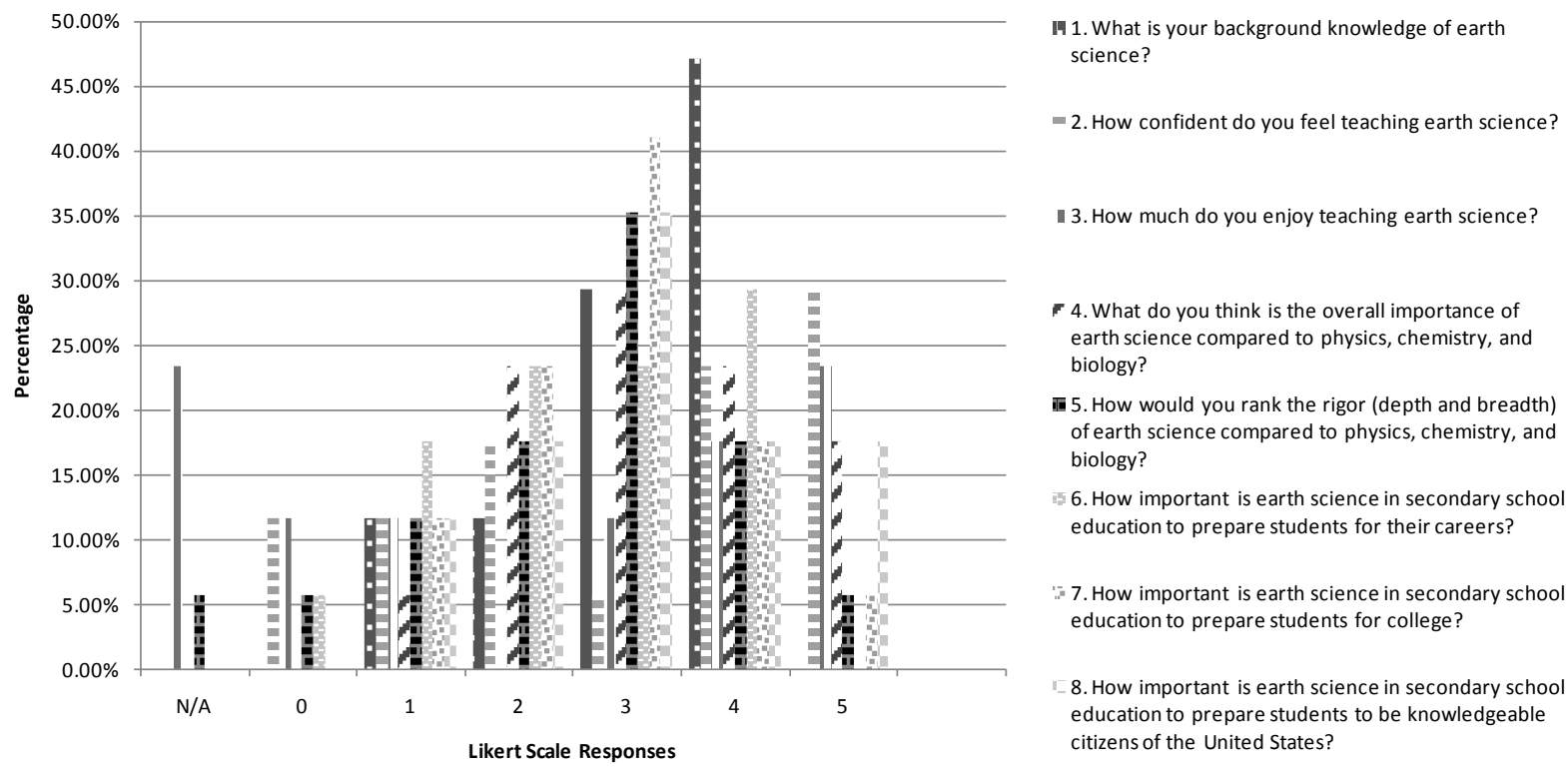

in 5. How would you rank the rigor (depth and breadth) of earth science compared to physics, chemistry, and biology?

6. How important is earth science in secondary school education to prepare students for their careers?

7. How important is earth science in secondary school education to prepare students for college?

8. How important is earth science in secondary schoo education to prepare students to be knowledgeable citizens of the United States?

Figure 4. Earth science teacher survey results from teachers who have taken 7 - 12 credit hours of Earth science in college.

Finally, the question of whether Earth science is important in secondary school education to prepare students to be knowledgeable citizens of the United States. A unexpectedly high percent of teachers (58) with 0 - 6 credit hours of Earth science said it is important or very important. About 35\% of teachers with 7 - 12 credit hours said it is important or very important and $40 \%$ of teachers with 13 or more credit hours said ESS is important or very important to prepare knowledgeable citizens.

\subsection{Statistical Analysis of Teacher Survey}

A two-way ANOVA, with weighted means to accommodate for unequal sample sizes, was calculated for each of the first eight questions on the teacher survey (Lowry, 2010). The test determined the significance of whether being an Earth science teacher improved a teacher's perceptions of Earth science and their perceptions of its educational value in secondary schools. The test also determined whether more ESS credit hours in college was 


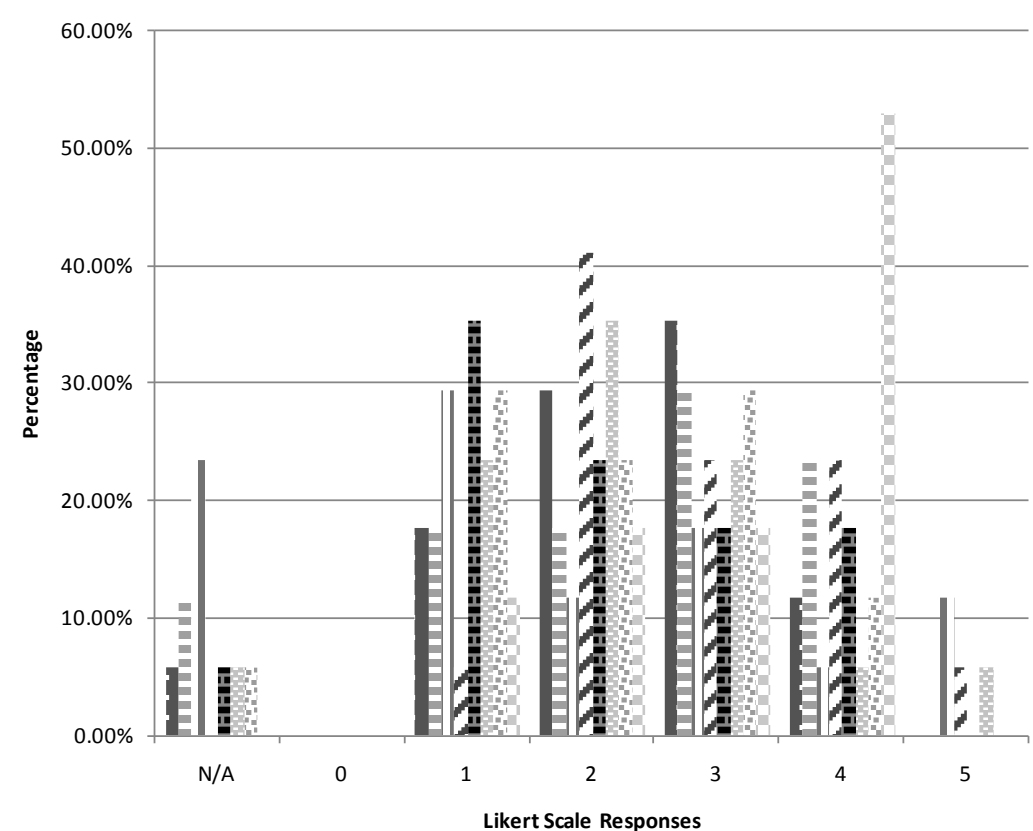

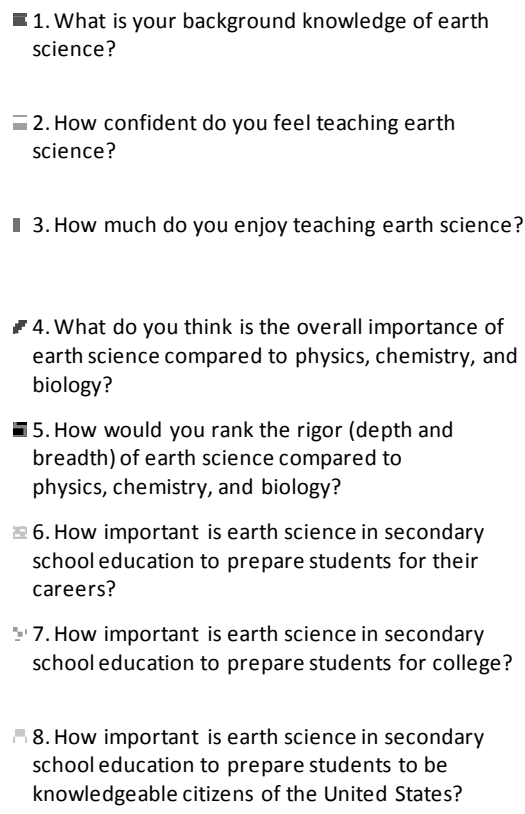

E 1 . What is your background knowledge of earth science?

$=2$. How confident do you feel teaching earth science?

II 3. How much do you enjoy teaching earth science?

4. What do you think is the overall importance of earth science compared to physics, chemistry, and biology?

a. How would you rank the rigor (depth and breadth) of earth science compared to physics, chemistry, and biology?

6. How important is earth science in secondary school education to prepare students for their careers?

7. How important is earth science in secondary school education to prepare students for college?

8. How important is earth science in secondary school education to prepare students to be knowledgeable citizens of the United States?

Figure 5. Earth science teacher survey results from teachers who have taken 13 or more credit hours of Earth science in college.

significant in teachers' perceptions of Earth science and its educational value in secondary schools. Teacher's answers on the Earth Science Teacher Survey served as the dependent variable and the independent variables were type of teacher (Earth science or non-Earth science), number of ESS credit hours in college (0 - 6, 7 - 12, or 13+), and type of teacher by number of ESS credit hours. ANOVA results for Questions 1 through 8 on the ESTS are reported in Table 4 and Table 5.

Questions 1 through 8 were divided into two subscales (see Table 2 for survey questions). Questions 1, 2, 3 and 5 assessed perceptions and questions 4, 6, 7, and 8 measured educational value. These two subscales (perceptions and educational value) contribute to the overall attitude of science teachers with regards to Earth science education in secondary schools.

Responses to questions 1, 2, and 3 showed that the type of teacher (Earth science or non-Earth science) was significant with regards to teacher knowledge, confidence, and enjoyment in teaching ESS, which was not unexpected. Question 5 did not show a significant main effect for Earth science/non-Earth science teachers beliefs of comparative rigor between ESS and other sciences. The amount of ESS credit hours in college was also significant for questions 1, 2, and 3, but not for question 5. Significance for type of teacher by number of credit hours was significant for question 2 only, suggesting a relationship between being an ESS teacher, completing more credit hours in Earth science, and being confident teaching Earth science, which supported our hypotheses.

For questions 4 - 8, which measured educational value, only question 7 showed that teacher-type was significant, meaning that ESS teachers really do feel that the course is important for students to take before they go to college. Responses to questions 4, 6, 7, or 8 did not show that the number of credit hours was significant. Lastly, teacher-type and number of ESS credit hours in college did not show significance for questions 4, 6, 7, and 8 .

\subsection{Student Survey Results}

Of 46 returned surveys, 20 were from females (43.5\%) and 26 from males (56.5\%); ages ranged from 13 to 18 years (Table 3). Surveyed students had taken and were currently taking a wide range of science courses including $6^{\text {th }}$ grade, $7^{\text {th }}$ grade, and $8^{\text {th }}$ grade science (which included Earth science components), astronomy, environmental science, physical science, biology, chemistry, and physics. Approximately 17\% of students said they were knowledgeable of ESS content (4 or 5 on Likert scale) and 47\% noted they held average knowledge of ESS (3 on Likert scale). Fifty percent of surveyed students said they highly or very highly enjoy learning about Earth science topics. However, when asked how important Earth science is compared to physics, chemistry and 
biology, only $30 \%$ said it is important or very important. Only $2.2 \%$ of respondents said that Earth science was very difficult compared with biology, chemistry, and physics and about $17 \%$ said it was moderately difficult.

When asked how important it is to have Earth science in middle school and/or high school as preparation for future jobs, $28 \%$ of students responded that it is important or very important. When asked how important it is to have ESS in middle school and/or high school to prepare them for college, a surprisingly high $48 \%$ responded that it is important or very important. A slightly lower $41 \%$ of students responded that having ESS in middle school and/or high school was important or very important to prepare them to be well-informed citizens of the United States.

Approximately $72 \%$ of students responding to the survey said that they had a moderate to very high interest in ESS. When asked how important ESS was to understanding issues like energy resources, climate change, and the absence of fresh water in many parts of the world, 83\% agreed that ESS was important or very important. About $61 \%$ of student respondents said that Earth science topics are easy or very easy to understand and approximately $74 \%$ said that more laboratory work and/or field trips would make Earth science topics easier to understand. Half of the students sampled in this study said that Earth science lessons are hands-on or very hands-on compared to physics, chemistry, and biology. Finally, about $30 \%$ of students stated that after taking ESS they are likely or very likely to consider a career in the Earth sciences.

\subsection{Statistical Analysis of Student vs. Teacher Surveys}

A two-tailed t-test (Table 6) was used to answer research item 3; comparing students' views towards ESS with teachers' views. The t-test assumed unequal variances and compared students' views and teachers' views for enjoyment level of learning and teaching ESS; the importance of ESS for college; the importance of ESS for students' future careers; Earth science's importance compared to physics, chemistry, and biology; and Earth science's importance in secondary education for preparing students to be knowledgeable citizens of the United States. The Likert scale answers for each question on the student survey were compared to the Likert scale answers on the teacher survey.

Enjoyment of teachers teaching Earth science was not significant when compared to enjoyment of students learning about Earth science. This is likely because at least 8 teachers answered N/A for this question and so their answers were not included in the averages for the t-test. The descriptive statistics show that student enjoyment is much higher than teacher enjoyment. Earth science's importance in secondary schools to prepare students for college was found to be significant. Students had more positive views of Earth science's educational value in preparing them for college.

In contrast, Earth science's importance in secondary schools to prepare students for their future careers was not found to be significant. This result parallels with the descriptive statistics, which show students and teachers feel similarly that ESS is not important for students' future careers. Earth science's importance compared to physics, chemistry, and biology was found to be significant, which also parallels the descriptive statistics that show students feel ESS is more important than teachers. Lastly, Earth science's importance in secondary school to prepare students to be knowledgeable citizens of the United States was not found to have a significant difference between students and teachers. Both students and teachers felt Earth science was not important to prepare students to be knowledgeable citizens of the United States.

\section{Discussion and Conclusion}

The purpose of this investigation was to analyze teacher and student perceptions of Earth science and ESS's educational value in secondary schools. Perceptions of teachers and students include the importance of ESS in the high school curriculum and general interest in the subject. Educational value refers to whether students and teachers think ESS is as important as physics, chemistry, and biology and whether ESS is as rigorous in depth and breadth as physics, chemistry, and biology. The research questions were (1) Do ESS teachers and non-ESS teachers differ on their perceptions toward ESS and its educational value in secondary schools? (2) Do teachers with varying number of ESS credit hours in college differ on their attitudes toward ESS? and (3) Do ESS attitudes differ between teachers and students?

The results of our investigation show that ESS teachers in this study have more positive perceptions of ESS than teachers who teach other science subjects, which is predictable. ESS teachers of this exploratory study have more ESS background, more confidence teaching Earth science, and enjoy teaching ESS more than non-ESS 
teachers. Non-ESS teachers have negative perceptions of ESS, which is evidenced by their lack of interest and enjoyment in teaching Earth science. These poor attitudes are related to a lack of background knowledge in ESS, which leads to a lack of confidence in teaching Earth science and space science.

As expected, Earth science teachers thought that Earth science in secondary schools has more educational value than non-Earth science teachers thought. Earth science teachers are more likely to think that Earth science is important for students to have in secondary school to prepare them to college. Though more ESS teachers thought that ESS was just as rigorous in depth and breadth as physics, chemistry and biology than non-ESS teachers, the difference wasn't conclusive. Still, the lack of background knowledge in ESS is likely a main reason that non-ESS teachers do not find Earth science as rigorous in depth and breadth as physics, chemistry, and biology. In addition, ESS teachers thought that Earth science was more important for students' future careers and to prepare students to be knowledgeable citizens than non-ESS teachers.

Having more ESS college credit hours did improve teachers' perceptions of Earth science, but did not improve how teachers felt about Earth science's educational value. We conclude that teachers with more credit hours in Earth science have more background knowledge of Earth science, were more confident teaching Earth science, and enjoyed teaching Earth science more than teachers with fewer credit hours of Earth science in college; again, not unexpected. However, although it appears in Figures 3-5 that more credit hours improve teachers' views towards Earth science's educational value, this cannot be statistically verified.

In contrast to teachers' attitudes, students have much more positive perceptions of Earth science and the educational value of ESS. The results of this study show that students have a high level of enjoyment learning about Earth science and also a high interest in learning about ESS topics. However, though the enjoyment level is higher than that of teachers, this difference could not be statistically verified in this study and should be explored further in future studies. Students also feel that Earth science is important in understanding major scientific problems. Students agree with teachers about the rigor of Earth science, finding ESS to be a fairly easy subject compared to physics, chemistry, and biology. Perhaps teachers who do not find ESS to be important don't have high expectations of their students.

Further studies, expanding beyond this exploratory regional research, could compare teacher attitudes to student attitudes with regards to ESS education in secondary schools nationally. Because the level of Earth science education that teachers possessed greatly affected their perceptions of Earth science education, studying attitudes of students who have teachers with greater Earth science backgrounds may further support the idea that teacher attitudes are passed to their students. In addition, research into the possibility of adding more Earth science curriculum to science teacher preparation programs should be considered. Research should be completed to determine whether the results of this study are a regional artifact or whether they are representative of other parts of the United States.

\section{References}

Benbow, A. E. (2011). Geoscience Currents. Report No. 44, American Geosciences Institute, Alexandria.

Dodick, J., \& Orion, N. (2003). Geology as a Historical Science: Its Perception within Science and the Education System. Science and Education, 12, 197-211. http://dx.doi.org/10.1023/A:1023096001250

Geological Society of America (2011). The Importance of Teaching Earth Science Position Statement. http://www.geosociety.org/positions/position4.htm

Gonzales, L. (2009). Status of the Geoscience Workforce. American Geosciences Institute, Alexandria.

Gonzales, L. (2011). Status of the Geoscience Workforce. American Geosciences Institute, Alexandria.

King, C. (2001). The Response of Teachers to New Subject Areas in a National Science Curriculum: The Case of the Earth Science Component. Science Education, 85, 636-664. http://dx.doi.org/10.1002/sce.1030

Lewis, E., \& Baker, D. (2010). A Call for a New Geoscience Education Research Agenda. Journal of Research in Science Teaching, 47, 121-129.

Lowry, R. (2010). Two-Way Anova. http://faculty.vassar.edu/lowry/anova2u.html

National Research Council (1996). National Science Education Standards. Washington, DC: National Academy Press.

National Research Council (2012). National Science Education Standards. Washington, DC: National Academy Press.

Oklahoma State Department of Education (2012). Oklahoma C3 Standards. http://ok.gov/sde/oklahoma-c3-standards 
Scientific Research Publishing (SCIRP) is one of the largest Open Access journal publishers. It is currently publishing more than 200 open access, online, peer-reviewed journals covering a wide range of academic disciplines. SCIRP serves the worldwide academic communities and contributes to the progress and application of science with its publication.

Other selected journals from SCIRP are listed as below. Submit your manuscript to us via either submit@scirp.org or Online Submission Portal.
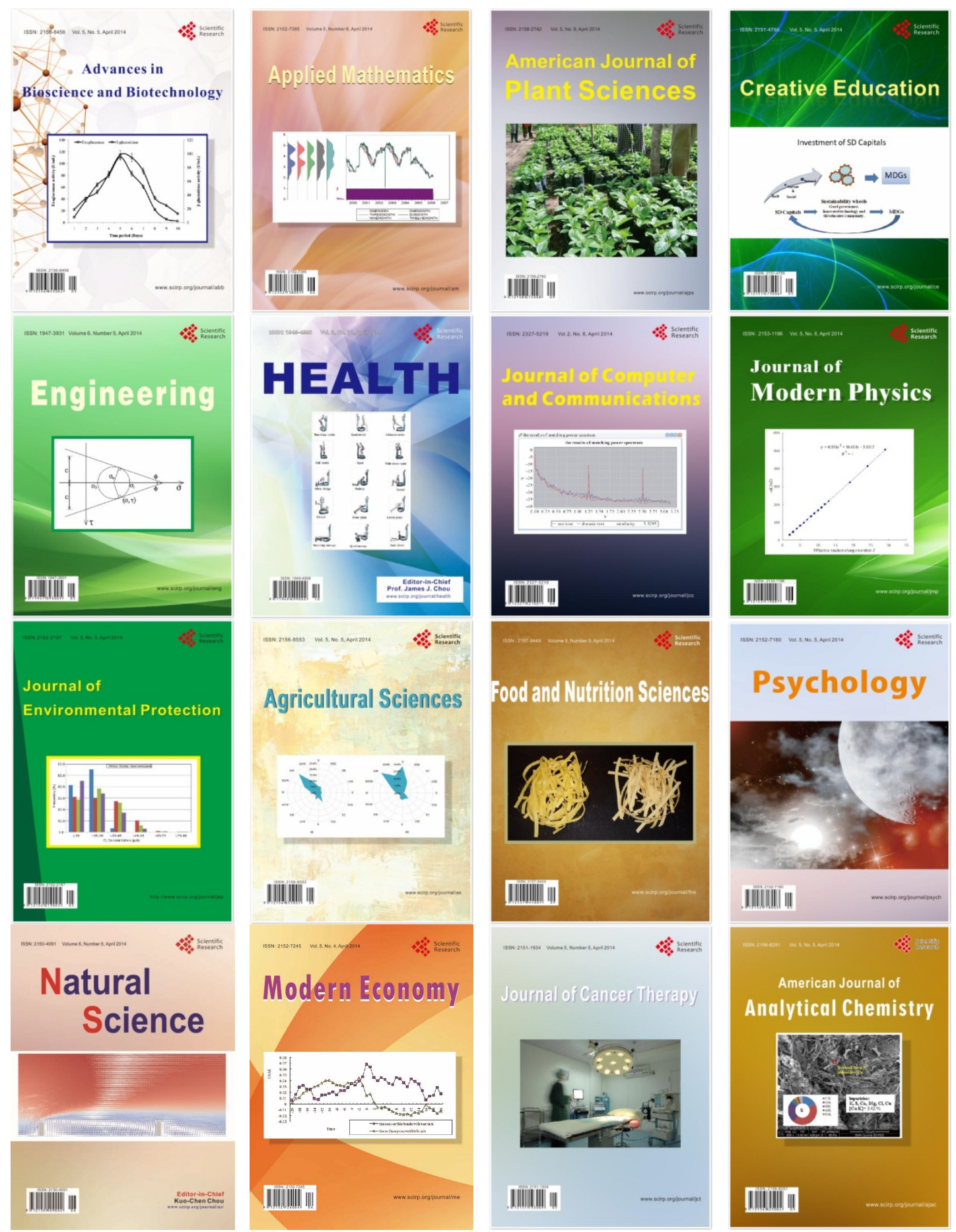